\title{
Nutrient dynamics and early decomposition rates of Picea abies needles in combination with Fagus orientalis leaf litter in an exogenous ecosystem
}

\author{
F. Ghasemi-Aghbash, V. Hosseini, M. Poureza
}

Ghasemi-Aghbash F., Hosseini V., Poureza M., 2016. Nutrient dynamics and early decomposition rates of Picea abies needles in combination with Fagus orientalis leaf litter in an exogenous ecosystem. Ann. For. Res. 59(1): 21-32.

Abstract. The Hyrcanian forests in the Northern Iran are originally poor of coniferous and are considered as a refugium of temperate broad-leaved trees during the Quaternary glaciations. In this study mass loss and nutrients dynamic of Norway spruce needles when combined with oriental beech litter was investigated in a 50-year plantation of pure Norway spruce in the Hyrcanian forests. The litter bags technique was used to monitor the mass loss and nutrients concentration after 60,120,180, 270 and 400 days. The results showed that when decomposed alone the mass loss rate of spruce needles was generally lower than what reported in Europe. However, when combined with oriental beech litter the mass loss rate was hastened compared to when decomposed alone. A positive non-additive effect of beech leaf litter was observed on spruce nutrients dynamic. The concentration of $\mathrm{N}, \mathrm{P}, \mathrm{K}$, and $\mathrm{Mg}$ in combined spruce needles with beech litter was generally higher compared to when spruce needles decomposed alone during decomposition time. While the concentration of $\mathrm{Mn}$ and $\mathrm{Ca}$ in combined spruce needles with beech litter was generally higher than when spruce needles decomposed alone. At the end of the decomposition period the release of $\mathrm{Mn}$ and $\mathrm{N}$ was significantly higher in combined spruce needles than when it decomposed alone. Based on the stepwise regression $\mathrm{N}$ was the only nutrient entered to model which explained $37 \%$ of mass loss variation. It was concluded that oriental beech leaf litter drive a non-additive effect on mass loss and nutrient dynamic of Norway spruce needles. Therefore combining the plantation of Norway spruce with oriental beech can result in better regulating of needles decomposition and nutrients cycle. Keywords decomposition, Hyrcanian forests, Norway spruce, non-additive, oriental beech

Authors. Farhad Ghasemi-Aghbash (ghasemifarhad@yahoo.com) - University of Malayer, Malayer, Iran; Vahid Hosseini - University of Kurdistan, Sanandaj, Iran; Morteza Poureza - Razi University, Kermanshah, Iran.

Manuscript received April 21, 2015; revised August 25, 2015; accepted September 2 , 2015; online first November 24, 2015. 


\section{Introduction}

Leaf litter decomposition is a key ecological process for nutrient cycles that is essential for forest ecosystem sustainability and net productivity (Purahong et al. 2014). This process is vital pathway for the return of energy, organic matter and nutrients from the vegetation to the soil through litter fall (Aber et al. 1990; Attiwill \& Adams, 1993; Kara et al. 2014). Nutrients bound in the organic matter are released to the soil in mineral form during decomposition (Gartner \& Cardon, 2004; Titus \& Malcolm, 1999; Berg \& Laskowski, 1997).

The amount of released nutrients depends on the amount of leaf litter fall and its decomposition rate (Guo \& Sims, 1999). On a global scale leaf litter production is generally dependent upon latitude and climate (Liu et al. 2006) while at a regional scale under similar temperature and precipitation regimes it is dependent upon the variation of ecological and physiological characteristics of tree species, site productivity, and physiographic factors (Barnes et al. 1998, Kara, et al. 2014). Decomposition rate is regulated by three main drivers including: decomposer communities, microclimate, and litter quality (Vesterdal 1999; Zhou et al. 2008; Berg et al., 2010).

The initial chemical components such as lignin concentration and contents of nutrients such as nitrogen $(\mathrm{N})$, and the carbon-to-nitrogen $(\mathrm{C}$ to $\mathrm{N})$ ratio are some of the most wellknown parameters of litter quality (Meentemeyer, 1984; Sariyildiz et al. 2005; Zhou et al., 2008). Differences between tree litter species as regards decomposition rate are closely related to the $\mathrm{C}$ to $\mathrm{N}$, and nitrogen-to-phosphorus $(\mathrm{N}$ to $\mathrm{P})$ ratios, as well as to contents of calcium (Ca) and manganese (Mn) (Berg at al., 2000; Aponte et al. 2012). The availability of litter as a substrate can influence the microbial decomposers' community and their activity and thus influence decomposition rate (Chapman et al. 2013). On the other hand climate parameters such as mean annual temperature
(MAT), mean annual precipitation (MAP) and actual evapotranspiration (AET) have also been reported as essential factors for decomposition rate (Berg \& McClaugherty, 2008).

Although several studies have related decomposition rates to climate factors it is commonly recognized that the rate of the microbially mediated decomposition is determined by an interaction of climate and substrate quality (Moorhead et al. 1999; Gholz et al. 2000; Silver \& Miya, 2001; Berger \& Berger, 2014). All these parameters can vary across the various forest ecosystems and their tree species communities.

In this study we intended to investigate decomposition rates of Norway spruce needle alone and combined with oriental beech leaf litter in a pure Norway spruce plantation as an introduced tree to the original site of oriental beech in the Hyrcanian forests. It is well documented that the mixing of leaf litters often causes non-additive decomposition in which the observed decomposition rate is often enhanced or retarded compared to what is expected when they decompose as single species (Gartner \& Cardon, 2004; Chapman et al. 2013). Overall, the interactions of litters from different species in one specific ecosystem influence decomposition rates of individual leaf types in mixes (Gartner \& Cardon, 2004). Consequently the nutrient cycles and nutrients' availability in soil can affect plant growth and activity of the decomposer community as well as the structure in soil (Gartner \& Cardon, 2004; Chapman et al. 2013).

There are some studies about the decomposition rates of Norway spruce needles when mixed with common beech (Fagus sylvatica) leaf litter in different site conditions (e.g., Albers et al. 2004; Berger et al. 2004; Berger et al. 2006; Berger \& Berger, 2014). The latest study of Berger \& Berger (2014) indicated that the decomposition rate of Norway spruce needle litter was higher in mixed than in spruce stands while the effect of litter species and their mixtures was not significant on 
decomposition rates. There is just one report about decomposition rates of Oriental spruce (Picea orientalis L.) needles mixed with oriental beech leaf litter indicating that mixed litters had higher decomposition rates than individual beech and spruce litters in both monocultures and mixed stands (Sariyildiz et al. 2005).

The differences in ecosystems and site conditions on one hand and using new species on the other hand makes it impossible to extrapolate the earlier findings to a new situation. So the main objectives of this study is to address the following questions: (i) What is the massloss rate of Norway spruce needles in an exogenous ecosystem which is historically poor in conifers? (ii) Does the oriental beech leaf litter increase the decay rates when combined with spruce needles? (iii) Do the nutrient concentrations and release rates differ when spruce litter decomposes individually or combined with beech leaf litter? Finding the answer of these questions is vital to decide about the ecological effect of an exogenous tree on a specific ecosystem in terms of nutrient cycling.

\section{Materials and methods}

\section{Study site}

This study was conducted in Hyrcanian forests as an exogenous ecosystem to Norway spruce. The Hyrcanian forests ecosystem, also called Caspian forests, covers the southern coast of the Caspian Sea in northern Iran.

The Hyrcanian forests are considered as one of the last remnants of natural deciduous forests in the world because they did not undergo major changes during the Quaternary Period (Shahsavari, 1997; Sagheb-Talebi et al. 2013). These forests are considered as a refugium of temperate broad-leaved trees during the Quaternary glaciations (Zohary, 1973; Sagheb-Talebi et al. 2013). They are rich in broadleaf species, with only a few species of endemic conifer trees including Italian cypress (Cupressus sempervirens), Oriental ar- bor-vitae (Platycladus orientalis), yew (Taxus spp.), and Greek juniper (Juniperusexcelsa) (Sagheb-Talebi et al. 2013). The sites that are dominated by oriental beech (Fagus orientalis lipsky) are the most productive stands of the Hyrcanian region (Sagheb-Talebi et al. 2013). The natural range of oriental beech extends from southeast Bulgaria through Turkey to the Hyrcanian forests. Some areas of these forests have been subjected to plantation with exogenous tree species especially coniferous species like Norway spruce (Picea abies) that is native to Europe.

In this study we chose a 50 years old pure stand of a Norway spruce plantation (34.1ha) in Lajim forest, $\left(36^{\circ} 14^{\prime} 46^{\prime \prime} \mathrm{N}, 53^{\circ} 7^{\prime} 13^{\prime \prime} \mathrm{E}\right.$, and $\left.36^{\circ} 14^{\prime} 41^{\prime \prime} \mathrm{N}, 53^{\circ} 7^{\prime} 33^{\prime \prime} \mathrm{E}\right)$ Mazandaran province in the central part of the Hyrcanian forests that is naturally covered by broadleaf species such as Oriental beech (Fagus orientalis), Persian maple (Acer velotinum) and Caucasian alder (Alnus subcurdata). However, some part of it have been subjected to stand conversion and plantation with exogenous coniferous trees. Site elevation range is about $850-965 \mathrm{~m}$ a.s.1., the mean annual precipitation (MAP) and mean annual temperature (MAT) are $17.3^{\circ} \mathrm{C}$ and $878.4 \mathrm{~mm}$, respectively. The climate is humid and moderate according to De Martonne method (De Martonne, 1926; Aghbash et al. 2014). The soil type is brown, the soil texture is clay with neutral to weak alkaline.

\section{Leaf litter collection and litterbag method}

Litter decomposition was determined using the litter-bag technique (Berg \& McClaugherty, 2008) under field conditions in a completely random design. Freshly shed leaves of oriental beech were collected from beech stands adjacent to the pure stand of Norway spruce in mid-November after clearing the soil surface (under the canopy) from the previous year leaf litter fall and then let the new leaves fall down. Norway spruce needles were collected from the all sides of the trees crown. The beech 
leaf litter was collected by spreading nets underneath the tree crown. The collected needles and leaf litters were air dried in the laboratory. Single-envelop and double-envelop nylon bags $(2 \mathrm{~mm}$ mesh) with $30 \times 20 \mathrm{~cm}$ in dimension we reemployed to determine the decomposition rate. $10.00 \mathrm{~g}$ air dried litter of each species were placed into bags according to the following way: 20 single-envelope bags with Norway spruce needles, 20 single-envelope bags with oriental beech litter and 20 doubleenvelope bags with beech and spruce litter separately in each envelope of bags. The bags were located throughout the Norway spruce plantation in October 2010. For the doubleenvelope bags the lower envelope filled with Norway spruce litter were located on the soil surface allowing nutrients to leach from beech litter from the upper envelope. Decomposition rate and dynamics of nutrients were monitored after $0,60,120,180,270$, and 400 days with 4 replication for each treatment including: pure Norway spruce litter and combined Norway spruce litter with beech litter.

\section{Laboratory analysis}

Before analyzing for nutrients, the air-dried litter samples were oven-dried at $70^{\circ} \mathrm{C}$ for $24 \mathrm{~h}$. Total N was determined by the Kjeldahl digestion method (Bremner and Mulvaney, 1982). The total content of elements such as $\mathrm{Mn}, \mathrm{Mg}$, $\mathrm{Ca}$, and $\mathrm{K}$ was measured using atomic absorption spectrometer (Issac, and Johnson, 1975). Available $\mathrm{P}$ was measured according to the Olsen method (Olsen and Dean, 1965). Acid-unhydrolyzable residue (AUR) (previously termed Klason lignin) was determined as the ash-free residue from the two-stage $\mathrm{H}_{2} \mathrm{SO}_{4}$ hydrolysis (Hatfield et al. 1994). The litter nutrient release was calculated as follows:

$$
R_{(\%)}=\frac{W_{0} C_{0}-W_{t} C_{t}}{W_{0} C_{0}} \cdot 100
$$

where $\mathrm{R}$ is nutrient release; $W_{0} W_{0}$ - the initial litter dry weight, $W_{t} W_{t}$ - dry weight of the remaining litter in litter bag when it was collected, $C_{o} C_{o}$ - nutrient concentration $(\mathrm{mg}$ $\left.\mathrm{g}^{-1}\right)$ in the initial litter, $C_{t} C_{\mathrm{t}}-$ nutrient concentration $\left(\mathrm{mg} \mathrm{g}^{-1}\right)$ in the remaining litter (Guo and Sims, 1999).

\section{Statistical analysis}

One-way ANOVA was used to compare the initial nutrient content of spruce and beech litter. Repeated measures ANOVA (MANOVA) was used to test the mass loss, nutrient concentration and nutrient release of spruce needles during decomposition period, followed by a set of contrasts to examine differences as affected by combination of beech litter. The stepwise regression was employed to find the best combination of chemical characteristics of litter to predict the mass loss as dependent variable.

The probability of $\mathrm{F}$ to entry and removal of independent variables was 0.5 and 0.10 respectively (SPSS IBM, New York, U.S.A).

\section{Results}

\section{Initial content of nutrients}

Initial concentrations of some nutrients such as $\mathrm{Mn}, \mathrm{Mg}, \mathrm{Ca}$, and $\mathrm{N}$ were significantly different between the spruce needles and beech leaf litter while those of $\mathrm{P}, \mathrm{K}$, and AUR were not (table 1). As shown in table 1 the initial values of $\mathrm{Mn}, \mathrm{Mg}$, and $\mathrm{Ca}$ content with $0.21,3.03$, and $10.42 \mathrm{mg}$ g-1, respectively were higher in beech leaf litter than in spruce litter with 0.05 , 1.50 , and $9.03 \mathrm{mg} \mathrm{g}^{-1}$. In the spruce litter the initial content of $\mathrm{N}\left(12.84 \mathrm{mg} \mathrm{g}^{-1}\right)$ was higher than that in beech leaf litter $\left(10.48 \mathrm{mg} \mathrm{g}^{-1}\right)$.

\section{Nutrient concentration during decomposition}

The result of repeated measures analysis (MANOVA) showed that the effect of factors including litter combination, time, and litter combination $\times$ time (table 2 ) were statistically 
significant for $\mathrm{N}, \mathrm{P}, \mathrm{K}, \mathrm{Ca}, \mathrm{Mg}$, and $\mathrm{Mn}$ concentration during decomposition.

The concentration of $\mathrm{P}$ in the spruce needles after 180 and 400 days of incubation was significantly higher in the combined needles than in the needles that were not combined (Fig. 2a). Two distinctive stages were observed in $\mathrm{P}$ concentration for all the litters during the monitoring time. $\mathrm{P}$ concentration was at the same level until day120, but increased sharply from day 180. The marginal mean (averaged across all levels) of $\mathrm{P}$ concentration was significantly lower $\left(3.18 \mathrm{mg} \mathrm{g}^{-1}\right)$ when spruce needles decomposed alone compared to when it combined with beech litter (3.69 $\mathrm{mg} \mathrm{g}^{-1}$ ) (table 3 ). It was not significantly difference between beech litter $\left(3.5 \mathrm{mg} \mathrm{g}^{-1}\right)$ and spruce needles alone or combined with beech litter.

The trend in Mn concentration of spruce needles when decomposed alone or combined with beech litter were very similar as compared to that for beech litter with higher fluctuation (Fig. 2b). The post hoc test indicated (table 3) that the marginal mean of Mn concentration in beech litter $\left(0.2 \mathrm{mg} \mathrm{g}^{-1}\right)$ was significantly higher than that in spruce needles when decomposed alone $\left(0.07 \mathrm{mg} \mathrm{g}^{-1}\right)$ and combined with beech litter $\left(0.06 \mathrm{mg} \mathrm{g}^{-1}\right)$.

The $\mathrm{Mg}$ concentration was significantly lower in spruce needles decomposing alone as compared to that combined with beech litter (Fig. 2c). In the day 60 the concentration of $\mathrm{Mg}$ increased both in pure spruce needles and when combined with beech litter. However the trend in $\mathrm{Mg}$ of beech litter was almost descending during decomposition time. Based on post hoc test (table 3) the marginal mean of $\mathrm{Mg}$ was significantly higher in beech litter $(2.35$ $\mathrm{mg} \mathrm{g}^{-1}$ ) compared to it in spruce needles when decomposed alone $\left(1.31 \mathrm{mg} \mathrm{g}^{-1}\right)$ and when the combined spruce with beech litter $(1.63 \mathrm{mg}$ $\left.\mathrm{g}^{-1}\right)$.

The decrease in K concentration was sharper at day 60 for beech litter and spruce needle compare to spruce needles combined with beech litter (Fig. 2d). The marginal mean (ta-

Table 1 Comparing the initial contents (mean \pm SE) of lignin/AUR and nutrients $\left(\mathrm{mg} \mathrm{g}^{-1}\right)$ of spruce (S) needles and beech (B) leaf litter using independent $t$-test. The different letters indicates statistically significant difference $(\mathrm{p}<0.05)$

\begin{tabular}{llllllrlll}
\hline Litter & $\mathrm{P}$ & $\mathrm{Mn}$ & $\mathrm{Mg}$ & $\mathrm{K}$ & $\mathrm{Ca}$ & $\mathrm{N}$ & $\mathrm{AUR}$ & $\mathrm{C}: \mathrm{N}$ & AUR:N \\
\hline \multirow{2}{*}{$\mathrm{S}$} & $1.27 \pm$ & $0.05 \pm$ & $1.50 \pm$ & $9.76 \pm$ & $9.03 \pm$ & $12.84 \pm$ & $292.66 \pm$ & $32.95 \pm$ & $22.78 \pm$ \\
& 0.19 & $0.01 \mathrm{~b}$ & $0.07^{\mathrm{b}}$ & 0.13 & $0.11^{\mathrm{b}}$ & $0.10^{\mathrm{a}}$ & 8.97 & $0.11^{\mathrm{b}}$ & $0.55^{\mathrm{b}}$ \\
$\mathrm{B}$ & $1.59 \pm$ & $0.21 \pm$ & $3.03 \pm$ & $9.85 \pm$ & $10.42 \pm$ & $10.48 \pm$ & $270.66 \pm$ & $39.76 \pm$ & $25.81 \pm$ \\
& 0.10 & $0.00^{\mathrm{a}}$ & $0.03^{\mathrm{a}}$ & 0.61 & $0.42^{\mathrm{a}}$ & $0.01^{\mathrm{b}}$ & 5.20 & $0.04^{\mathrm{a}}$ & $0.46^{\mathrm{a}}$ \\
\hline
\end{tabular}

Table 2 Repeated measures analysis of variance on the difference ( $F$ value) in leaf litter N, P, K, Ca, Mn, $\mathrm{Mg}$, and lignin of the litter and spruce and mixture of spruce and beech

\begin{tabular}{lrrrrrrrr}
\hline Factor & df & \multicolumn{1}{l}{$\mathrm{N}$} & $\mathrm{P}$ & $\mathrm{K}$ & $\mathrm{Ca}$ & $\mathrm{Mn}$ & $\mathrm{Mg}$ & \multicolumn{1}{l}{$\mathrm{AUR}$} \\
\hline Litter & & $28.68^{* *}$ & $1.62^{*}$ & $22.69^{* *}$ & $71.10^{* *}$ & $0.14^{* *}$ & $6.79^{* *}$ & $57.42^{* *}$ \\
mixing & 2 & $(136.95)$ & $(5.43)$ & $(182.04)$ & $(35.85)$ & $(945.93)$ & $(478.87)$ & $(151.90)$ \\
\hline \multirow{2}{*}{ Time } & & $42.28^{* *}$ & $144.59^{* *}$ & $216.49^{* *}$ & $404.85^{* *}$ & $0.10^{* *}$ & $2.05^{* *}$ & $66.89^{* *}$ \\
& 5 & $(268.44)$ & $(462.09)$ & $(446.81)$ & $(71.67)$ & $(6.91)$ & $(60.89)$ & $(28.48)$ \\
\hline Time x litter & & 2.89 & $2.29^{* *}$ & $4.87^{* *}$ & $24.99^{*}$ & $0.01^{* *}$ & $0.38^{* *}$ & $12.35^{* *}$ \\
mixing & 10 & $(18.47)^{* *}$ & $(7.27)$ & $(10.05)$ & $(4.42)$ & $(4.56)$ & $(11.46)$ & $(5.25)$ \\
\hline
\end{tabular}

Note. The data from table represent the mean square (F value). Level of significance: $*_{-} \mathrm{p}<0.05 ; *_{-} \mathrm{p}<0.01$. 
Table 3 The result of the Bonferroni post hoc test to compare marginal mean of nutrients.

\begin{tabular}{lrrr}
\hline \multirow{2}{*}{ Nutrients } & Litters & \multicolumn{1}{c}{$\mathrm{B}$} & $\mathrm{S}(\mathrm{S}+\mathrm{B})$ \\
\cline { 2 - 4 } & $\mathrm{S}$ & $3.50^{\mathrm{ab}}$ & $3.69^{\mathrm{a}}$ \\
$\mathrm{n}\left(\mathrm{mg} \mathrm{g}^{-1}\right)$ & $3.18^{\mathrm{b}}$ & $13.47^{\mathrm{c}}$ & $15.66^{\mathrm{a}}$ \\
$\mathrm{N}\left(\mathrm{mg} \mathrm{g}^{-1}\right)$ & $14.50^{\mathrm{b}}$ & $13.41^{\mathrm{b}}$ & $13.92^{\mathrm{b}}$ \\
$\mathrm{Ca}\left(\mathrm{mg} \mathrm{g}^{-1}\right)$ & $16.61^{\mathrm{a}}$ & $3.22^{\mathrm{b}}$ & $4.63^{\mathrm{a}}$ \\
$\mathrm{K}\left(\mathrm{mg} \mathrm{g}^{-1}\right)$ & $2.76^{\mathrm{c}}$ & $0.20^{\mathrm{b}}$ & $0.06^{\mathrm{a}}$ \\
$\mathrm{Mn}\left(\mathrm{mg} \mathrm{g}^{-1}\right)$ & $0.07^{\mathrm{c}}$ & $2.35^{\mathrm{a}}$ & $1.63^{\mathrm{b}}$ \\
$\mathrm{Mg}\left(\mathrm{mg} \mathrm{g}^{-1}\right)$ & $1.31^{\mathrm{c}}$ & $29.40^{\mathrm{b}}$ & $32.03^{\mathrm{a}}$ \\
\hline
\end{tabular}

Note. Abbreviations: B stands for beech litter, $\mathrm{S}$ for spruce and $\mathrm{S}(\mathrm{S}+\mathrm{B})$ for combined.

ble 3 ) of $\mathrm{K}$ concentration in litter combination (4.63 $\mathrm{mg} \mathrm{g}^{-1}$ ) was significantly higher than that in beech litter $\left(3.22 \mathrm{mg} \mathrm{g}^{-1}\right)$ and spruce needles $\left(2.76 \mathrm{mg} \mathrm{g}^{-1}\right)$.

The general trend in $\mathrm{Ca}$ concentration was similar for all the litters with the concentration at its peak on day 120 (Fig 2e). The Bonferroni post hoc test indicated (table 3 ) that the marginal mean of $\mathrm{Ca}$ concentration was higher in spruce litter decomposing alone $(16.61 \mathrm{mg}$ $\left.\mathrm{g}^{-1}\right)$ as compared to when combined with beech litter (13.92 $\left.\mathrm{mg} \mathrm{g}^{-1}\right)$ and in beech litter (13.41 $\left.\mathrm{mg} \mathrm{g}^{-1}\right)$. However, no significant difference of the marginal mean of $\mathrm{Ca}$ concentration was observed between spruce needles combined with beech litter and beech litter.

The concentration of $\mathrm{N}$ during decomposition period was significantly higher in spruce needles combined with beech litter than in both spruce needles not combined and beech litter (Fig. 2f). The Bonferroni post hoc test indicated that the marginal mean of $\mathrm{N}$ concentration in combined spruce needles with beech litter (15.66 $\mathrm{mg} \mathrm{g}^{-1}$ ) was significantly higher than it in non-combined spruce needles $(14.50$ $\left.\mathrm{mg} \mathrm{g}^{-1}\right)$ and beech litter (13.64 $\mathrm{mg} \mathrm{g}^{-1}$ ).

The trend of AUR concentration was almost the same for spruce needles when decomposed alone and combined with beech litter. It was significantly lower in beech litter up until day 180 but afterward increased sharply and stayed as the same level as in spruce needles. The post hoc test indicated (table 3 ) that AUR concentration was significantly lower in beech litter
(29.40 $\mathrm{mg} \mathrm{g}^{-1}$ ) compared to that in spruce needles both when decomposed alone $(32.13 \mathrm{mg}$ $\left.\mathrm{g}^{-1}\right)$ and combined with beech litter $(32.03 \mathrm{mg}$ $\left.\mathrm{g}^{-1}\right)$.

The accumulated mass loss was not significantly different between non-combined spruce needles and those combined with beech litter for the main part of the incubation period (Fig. $2 \mathrm{~h})$. However, on day 400 the rate of mass loss (\%) in combined spruce needles with beech litter was significantly higher than it in spruce needles alone. The rate of mass loss in beech litter was significantly lower on day 180 and afterward as compared to spruce needles both combined and non-combined.

\section{Litter nutrient release}

As shown in the Fig. 3a there was a retention of $\mathrm{N}$ in the first steps of decomposition instead of a release. For the spruce needles combined with beech litter no $\mathrm{N}$ release was observed until day 270 and afterwards (Fig 3a). For the non-combined spruce needle no $\mathrm{N}$ release was observed only on the days 180 and 270 . The effect of time, litter combination, and time $\times$ litter combination on $\mathrm{N}$ release was statistically significant $(p<0.01)$ according to the results of repeated measures analysis (table 4 ).

There was no AUR decomposition in the first step of litter decay (Fig. 3b). The rate of AUR decomposition was increasing from the census day 180 to day 400 both for spruce needles alone or combined with beech litter. 

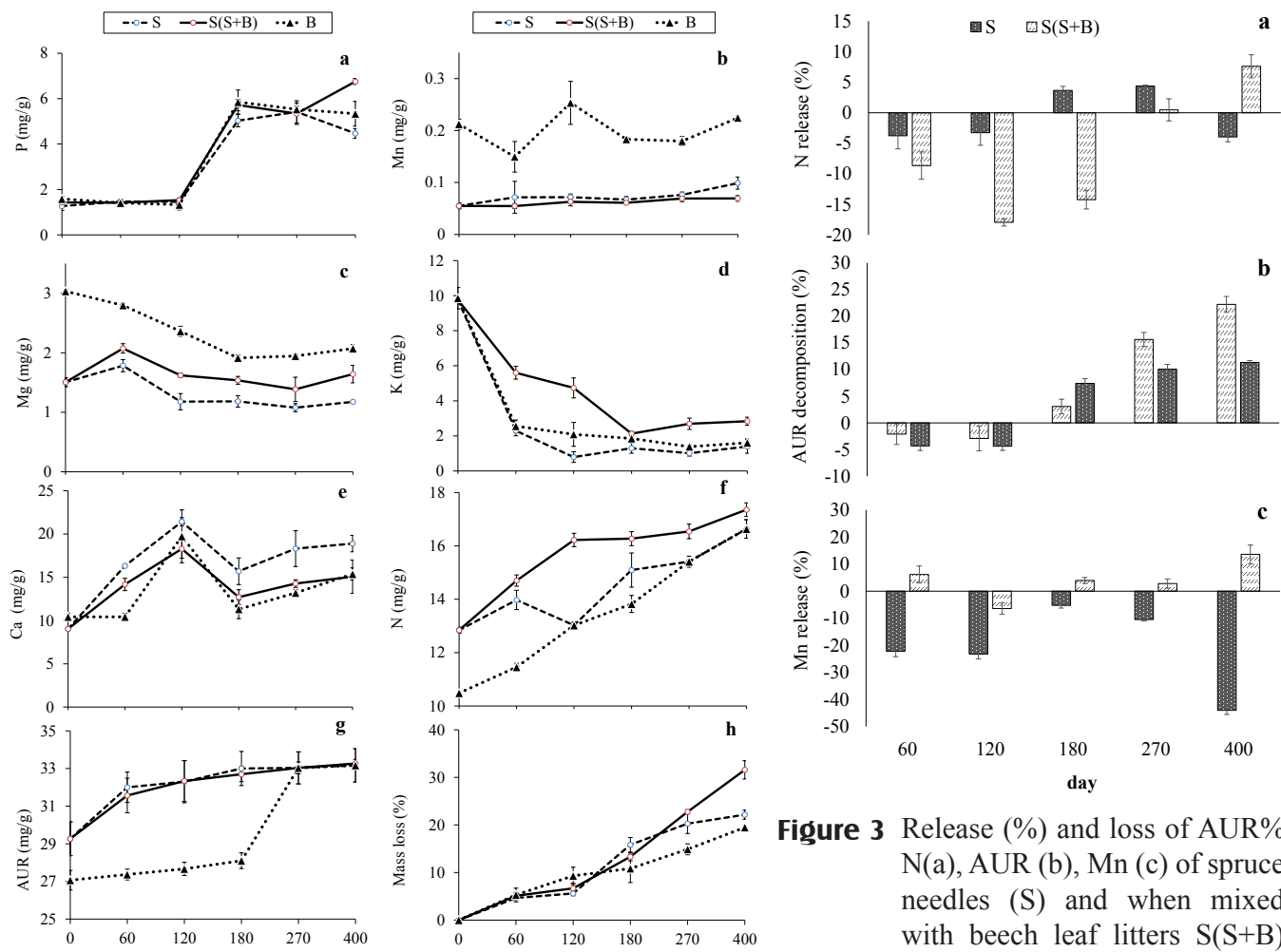

Figure 3 Release (\%) and loss of AUR\% N(a), AUR (b), Mn (c) of spruce needles (S) and when mixed with beech leaf litters $\mathrm{S}(\mathrm{S}+\mathrm{B})$ $($ Mean $\pm \mathrm{SE}$ )

Figure 2 Litter mass loss \% (h) and concentrations of the nuDifferent letters indicate significant difference between the mean of nutrient release, when spruce needles decomposed alone $(\mathrm{S})$ and when combined with beech leaf litter $(\mathrm{S}(\mathrm{S}+\mathrm{B}))$

However it was significantly higher in spruce needles combined with beech litter as compare to spruce needles alone in day 270 and afterwards. The results of repeated measures analysis indicated that the effect of time, litter combination, and time $\times$ litter combination on AUR release was statistically significant $(p<0.01)$ (table 3).

No Mn release was observed in spruce needle when decomposed alone (Fig. 3c). While $\mathrm{Mn}$ release was observed for spruce needles combined with beech litter during the incubation period except for on day 120. The effect of time, litter combination and time $\times$ litter combination on $\mathrm{Mn}$ release was significant at $p<$ 0.01(repeated measure analysis) (table 3).

According to the result of stepwise regression
$\mathrm{N}$ was the only initial chemical characteristic of litters that was entered to the model which could explained $37 \%$ of mass loss variation (table 5).

\section{Discussion}

\section{Litters combination effect}

The finding of our results indicated the positive no-additive effect of beech litter on spruce needles decomposition. The non-additive effects of litter mixing have been frequently reported for different species (Chapman et al. 2013). Based on this hypothesis we investigated the decomposition rates of spruce needles 
Table 4 Repeated measures analysis of variance on the difference ( $F$ value) on release of nutrients (N, Mn and AUR) decomposition of spruce needles when decomposed alone and mixed with beech leaf litter (level of significance $p<0.01$ )

\begin{tabular}{lrrrr}
\hline Factor & df & $\mathrm{N}$ & Mn & AUR \\
\hline \multirow{2}{*}{ Litter mixing } & & $353.90^{* *}$ & $6289.06^{* *}$ & $99.82^{* *}$ \\
\hline \multirow{2}{*}{ Time } & 1 & $(52.92)$ & $(1545.24)$ & $(18.00)$ \\
\hline \multirow{2}{*}{ Time x litter mixing } & 5 & $473.88^{* *}$ & $728.28^{* *}$ & $123.69^{* *}$ \\
& 5 & $(55.85)$ & $(36.49)$ & $(234.25)$ \\
\hline
\end{tabular}

Table 5 Stepwise regression information for dependent variables (Mass loss \%) and explanatory variables (P, Mn, Mg, K, Ca, N, AUR, C:N, and AUR:N)

\begin{tabular}{llllllll}
\hline $\begin{array}{l}\text { Dependent } \\
\text { Variable }\end{array}$ & \multirow{2}{*}{ Model } & $\begin{array}{l}\text { Adj. } R \\
\text { square }\end{array}$ & $\begin{array}{l}d f \\
\text { Reg. }\end{array}$ & $\begin{array}{l}d f \\
\text { Res. }\end{array}$ & $\begin{array}{l}M S \\
\text { Reg. }\end{array}$ & $\begin{array}{l}M S \\
\text { Res. }\end{array}$ & Sig. \\
\hline Mass Loss \% & $\mathrm{N}$ & 0.37 & 1 & 11 & 154.3 & 20.4 & 0.02 \\
\hline
\end{tabular}

Note. Abbreviations: Adj. $R$ square: Adjusted $\mathrm{R}$ square, df Reg.: degree of freedom regression, $\mathrm{df}$ Res.: degree of freedom residuals, $M S$ Reg.: mean of square regression, $M S$ Res.: mean of square residuals, Sig.: significance

in an exogenous ecosystem under the influence of nutrient leaching from oriental beech. In other words in this study the spruce needles was not mixed with beech litter but combined. Placing spruce needles and beech in a one bag but in two separate pockets allowed to precisely monitor the effect of nutrient leaching effect from beech on decomposition rates of spruce needles and nutrient dynamics.

\section{Mass loss of litter and litter quality}

When decomposed alone the accumulated mass loss of spruce needles was $22.15 \%$ after 400 days incubation. The results of Berger \& Berger (2014) indicated 31\% mass loss of spruce needles after one year. Having the lower $\mathrm{C}$ to $\mathrm{N}$ and Lignin to $\mathrm{N}$ ration in initial spruce needles in Hyrcanian forests did not result in a faster decomposition rate compared to the decomposition in its original ecosystem based on the report of Berger \& Berger (2014). However, our results was close to the lower range of first-year mass loss (19.4-32.8\%) that Berg et al. (2000) reported along a climate transect in Sweden.

The ratios of AUR to $\mathrm{N}$ and $\mathrm{C}$ to $\mathrm{N}$ in spruce needles were significantly lower than in beech leaf litter. In the current study the ratio of $\mathrm{C}$ to $\mathrm{N}$ in spruce needles (32.95) and the ratio of AUR to $\mathrm{N}$ (22.78) was lower than the range reported by Berger \& Berger (2014) for C to $\mathrm{N}$ ratio (53.7-58.4) and AUR to $\mathrm{N}$ ratio (30$\left.32.3 \mathrm{mg} \mathrm{g}^{-1}\right)$. The ratios of $\mathrm{C}$ to $\mathrm{N}$ and AUR to $\mathrm{N}$ are of the most important traits of leaf litters explaining the most variations in decomposition rates worldwide (Gartner \& Cardon, 2004; Zhang et al.2008; Talbot \& Tresder, 2012).

In our study although there was a significant difference of initial $\mathrm{Mn}, \mathrm{Mg}, \mathrm{Ca}, \mathrm{C}$ to N, AUR to $\mathrm{N}$ and $\mathrm{N}$ concentration between the beech litter and spruce needles, $\mathrm{N}$ was the best initial chemical variable to explain variation of decomposition rate $(37 \%)$. In contrast the results of Sariyildiz et al. about the decomposition rates of Picea orientalis and Fagus orienta- 
lis indicated that spruce needles decomposed more rapidly than beech litters and initial lignin of litters explained most of the variation of decomposition rates. On the other hand the results of Zhang et al. (2008) indicated that a combination of litter chemical characteristics including $\mathrm{C}$ to $\mathrm{N}$, lignin to $\mathrm{N}$, lignin and $\mathrm{N}$ could explain over $73 \%$ of variations of decay rates worldwide. However, the finding of Berg et al. (2000) indicated the initial Mn content of spruce needles is of the most important factor controlling the site-to-site variation of decomposition rates. There are several studies demonstrating that decomposition rate is controlled not only by litter quality but also by an interaction of climate and substrate quality and microbial community (Silver \& Miya, 2001; Zhang et al. 2008; Chapman et al. 2013; Berger \& Berger, 2014).

\section{Nutrient dynamics}

The nutrient concentrations of spruce needles were significantly affected by the combination with beech leaf litter. When combined with leaf litter of oriental beech, accumulated mass loss did not increase significantly at least until 270 days after incubation. However, at the end of the incubation period (day 400) the mass loss rates of spruce needles combined with beech leaf litter was $9.4 \%$ more than in spruce needle alone. This result is consistent with the results of Berger \& Berger (2014) that indicated admixing spruce needles with $50-75 \%$ beech leaf litter hastened the mass loss rates during the first year of decomposition. Therefore the second question of this study that was whether the oriental beech leaf litter hasten the decay rates when combined with spruce needles, is answered.

The increasing of $\mathrm{N}$ concentration in spruce needles both when decomposed alone and combined with beech leaf litter is comparable with the results of previous studies. The results of Alber et al. (2004) indicated that N was accumulated during the first year of decomposition that supports our findings. The immobilization of $\mathrm{N}$ during the first stage of decomposition is the reason of $\mathrm{N}$ accumulation (Aber et al. 1990). In our results the initial N content in spruce needles was higher than in the beech leaf litter and the accumulation of $\mathrm{N}$ was higher when spruce needles combined with beech leaf litter. However, the $\mathrm{N}$ release of spruce needles was higher than it when combined with beech leaf litter. The possible $\mathrm{N}$ transfer from beech leaf litter to spruce needles can be explain the changes of $\mathrm{N}$ concentration and release in spruce needles when combined with beech litter which is supported by the results of previous studies (Zhang et al. 2014). In the first stages of decomposition the releasing of $\mathrm{N}$ can positively affect litter decomposition rates. In other words, the more $\mathrm{N}$ release in spruce needles, the more mass loss occur (Berg \& McClaugherty, 2008)

The pattern of $\mathrm{P}$ concentration varied with time. In our result we observed two stages of $\mathrm{P}$ concentration. In the first stage (up to day 120) the concentration of $\mathrm{P}$ was low compared to the second stage (days 180-400) that was remarkably increased. There are different reports about $\mathrm{P}$ content indicating both release and fixation of $\mathrm{P}$ in the first stages of leaf litter decomposition for various species (Titus \& Malcolm, 1999; Berg \& Laskowski, 1997). In our study the increasing $\mathrm{P}$ content after 400 days when spruce needles combined with beech leaf litter is consistent with the results of Berger \& Berger (2014) indicated generally the remaining $\mathrm{P}$ content of spruce needles increased in the first year of decomposition when combined with beech leaf litter compare to when spruce needles decomposed alone.

The decreasing of $\mathrm{K}$ concentration during decomposition period indicated its rapid leaching when spruce needles decompose alone and combined with beech leaf litter. However, a negative non-additive effect of beech leaf litter combination was observed. $\mathrm{K}$ is a highly mobile cation that rapidly leaches out from the foliage (Laskowski et al. 1997). Our finding is consistent with the results of Titus \& Malcolm (1999) about Sitka spruce needles that indicat- 
ed a rapid exponential decrease of $\mathrm{K}$ content in the first year with approximately $80 \%$ lost. Berger \& Berger (2014) observed no decrease in $\mathrm{K}$ content of spruce needles when mixed with beech leaf litter (with portion 50\% and $50 \%$ ) in the pure spruce stand in the first year.

Unlike to $\mathrm{Ca}$, the $\mathrm{Mg}$ concentration of spruce needles was increased when combined with the beech leaf litter during the decomposition. The study of Berger \& Berger (2014) indicated that when spruce needles mixed with beech leaf litter (with portion $50 \%$ ) the concentration of $\mathrm{Mg}$ and $\mathrm{Ca}$ in spruce needles decreased more than when the spruce needles decomposed alone after one year of decomposition in the spruce stand. Our finding indicated a positive nonadditive effect of beech leaf litter combining on $\mathrm{Mn}$ release of spruce needles. Berg et al. (2000) reported that the lignin concentration can be regulated by the concentration of $\mathrm{Mn}$.

The third question of this study that was whether the nutrient concentration and release differs when spruce litter decomposed individually or combined with beech leaf litter is answered. The brief answer is that the combining beech leaf litter to spruce needles increased the concentration of the nutrients such as $\mathrm{N}, \mathrm{Mg}, \mathrm{P}$ and $\mathrm{K}$. While the concentration of the other nutrients such as $\mathrm{Ca}$ and $\mathrm{Mn}$ and as well as AUR was not affected by the combining beech leaf litter during decomposition period.

\section{Conclusions}

Our findings indicated that the combining Norway spruce needles with beech litter can drive non-additive effect on decomposition and nutrients dynamic. The mass loss rate of Norway spruce needles can be increased by combining them with beech litter. The main conclusion of this study is that combining the Norway spruce plantations with oriental beech in the Hyrcanian forests can result in better regulating of spruce needles decomposition and nutrients cycle.

\section{Acknowledgments}

We would like to thank Björn Berg for proof reading and commenting on earlier versions of this manuscript. The constructive comments of the anonymous reviewer is gratefully acknowledge.

\section{References}

Aber JD., Melillo JM., McClaugherty CA., 1990. Predicting long-term patterns of mass loss, nitrogen dynamics, and soil organic matter formation from initial fine litter chemistry in temperate forest ecosystems. Canadian Journal of Botany 68:2201-2208. DOI: 10.1139/b90287

Aghbash F.Gh., Jalali Gh.A., Hosseini V., Hosseini M., Berg B., 2014. Study of the relationship of nutrients dynamics and chemical composition of litter with decomposition rate in late decomposition stages Journal of plant research 27: 715-727 [In Persian]

Albers D., Migge S., Schaefer M., Scheu S., 2004. Decomposition of beech leaves (Fagus sylvatica) and spruce needles (Picea abies) in pure and mixed stands of beech and spruce. Soil Biology and Biochemistry 36:155-164. DOI: 10.1016/j.soilbio.2003.09.002

Aponte C., Garcia VL., Mara-ón T., 2012. Tree species effect on litter decomposition and nutrient release in Mediterranean oak forests change over time. Ecosystems 15, 1204-1218. DOI: 10.1007/s10021-012-9577-4

Attiwill PM., Adams MA., 1993. Tansley review No. 50. Nutrient cycling in forests. New Phytologist. 124, 561582. DOI: 10.1111/j.1469-8137.1993.tb03847.x

Barnes BV., Zak DR., Denton SR., Spurr SH., 1998. Forest Ecology. 4th edition. New. York, John Wiley and Sons, Inc. $774 \mathrm{p}$.

Ber g B., 2000. Litter decomposition and organic matter turnover in northern forest soils. Forest Ecology and Management 133: 13-22.

Berg B., McClaugherty CA., 2008. Plant litter: Decomposition, Humus Formation, Carbon Sequestration. Springer-Verlag Berlin Heidelberg. 338 p. DOI: 10.1007/978-3-540-74923-3

Berg B., Laskowski R., 1997. Changes in nutrient concentrations and nutrient release in decomposing needle litter in monocultural systems of Pinus contorta and Pinus sylvestris - a comparison and synthesis. Scandinavian Journal of Forest Research 12:113-121. DOI: 10.1080/ 02827589709355392

Berg B., Davey MP., De Marco A., Emmett B., Faituri M., Hobbie SE., Johansson MB., Liu C., McClaugherty CA., Norrell L., Rutigliano FA., Vesterdal L., Virzo De Santo A., 2010. Factors influencing limit values for pine needle litter decomposition: a synthesis for boreal and temperate pine forest systems. Biogeochemistry, 100: 57-73. DOI: 10.1007/s10533-009-9404-y 
Berg B., Johansson MB., Meentemeyer V., 2000. Litter decomposition in a transect of Norway spruce forests: substrate quality and climate control. Canadian Journal of Forest Research 30, 1136-1147. DOI: 10.1139/x00044

Berger T., Berger P., 2014. Does mixing of beech (Fagus sylvatica) and spruce (Picea abies) litter hasten decomposition? Plant Soil 377:217 -234. DOI 10.1007/ s11104-013-2001-9.

Berger TW., Köllensperger G., Wimmer R., 2004. Plantsoil feedback in spruce (Picea abies) and mixed spruce-beech (Fagus sylvatica) stands as indicated by dendrochemistry. Plant Soil 264:69-83. DOI: 10.1023/ B:PLSO.0000047714.43253.25

Berger TW., Swoboda S., Prohaska T., Glatzel G., 2006. The role of calcium uptake from deep soils for spruce (Picea abies) and beech (Fagus sylvatica). Forest Ecology and Management 229: 2 34-246.

Bremner JM., Mulvaney CS., 1982. Nitrogen-Total. In: Page, A.L.,Miller, R.H., and Keeney, D.R.(Eds), Methods of Soil Analysis, Part 2. Chemical and Microbiological Properties. ASA, SSSA, WI: 595-624.

Chapman SK., Newman GS., Hart SC., Schweitzer GA., Koch GW., 2013. Leaf Litter Mixtures Alter Microbial Community Development: Mechanisms for Non-Additive Effects in Litter Decomposition. PloS ONE 29; 8(4):e62671. DOI: 10.1371/journal.pone.0062671

De Martonne E., 1926. Aerisme, et índices d'aridite. Comptes rendus de l'Academie des Sciences 182:13951398.

Gartner T B., Cardon ZG., 2004. Decomposition dynamics in mixed-species leaf litter. Oikos 104: 230-246. DOI: 10.1111/j.0030-1299.2004.12738.x

Gholz HL., Wedin DA., Smitherman SM., Harmon ME., Parton WJ., 2000. Long-term dynamics of pine and hardwood litter in contrasting environments: toward a global model of decomposition. Global Change Biology 6:751- 765. DOI: 10.1046/j.1365-2486.2000.00349.x

Guo LB., Sims REH., 1999. Litter decomposition and nutrient release via litter decomposition in New Zealand eucalypt short rotation forests. Agriculture, Ecosystems \& Environment 75(1-2):133-140. DOI: 10.1016/ S0167-8809(99)00069-9

Hatfield RD., Jung HG., Ralph J., Buxton D.R., Weimer PJA.,1994. Comparison of the insoluble residues produced by the Klason lignin and acid detergent lignin procedures. Journal of Science of Food and Agriculture 65: 51-58. DOI: 10.1002/jsfa.2740650109

IBM Corp. Released 2012. IBM SPSS Statistics for Windows, Version 21.0. Armonk, NY: IBM Corp.

Issac RA., Johnson WC., 1975. Colloborative study of wet and dry techniques for the elemental analysis of plant tissue by atomic absorption spectrometer. Journal of Association of Agricultural chemist 58: 436-440.

Kara O., Bolat I., Cakıroglu K., Senturk M., 2014. Litter Decomposition and Microbial Biomass in Temperate Forests in Northwestern Turkey. Journal of Soil Science and Plant Nutrient 14: 31-41 DOI: 10.4067/S0718

\section{3}

Laskowski R., Berg B., Johansson M., McClaugherty CA., 1995. Release pattern for potassium from decomposing forest leaf litter. Long-term decomposition in a Scots pine forest XI. Canadian Journal of Botany 73:20192027. DOI: $10.1139 / \mathrm{b} 95-216$

Leroy S., Stevens L., Lahijani H., Brewer S., 2008. A late Pleistocene long pollen record from Lake Urmia, NW Iran. Quaternary Research 69:413-420 DOI: 10.1016/j. yqres.2008.03.004

Meentemeyer V., 1984. The geography of organic decomposition rates. Annals of the Association of American Geographers 74:551 - 560. DOI: 10.1111/j.14678306.1984.tb01473.x

Monleon VJ., Cromack K., 1996. Long-term effects of prescribed under burning on litter decomposition and nutrient release in ponderosa pine in central Oregon. Forest Ecology and Management 81:143-152. DOI: 10.1016/0378-1127(95)03658-X

Moorhead DL., Currie WS., Rastetter EB., Parton WJ., Harmon ME., 1999. Climate and litter qality controls on decomposition: An analysis of modeling approaches. Global Biogeochemical Cycles 13:575-589. DOI: 10.1029/1998GB900014

Olsen SR., Dean L., 1965. Phosphourus. In:Black, C.A.(Eds), methods of soil Analysis, Part2. American Society of Agronomic, Mddison,pp.1044-1047.

Purahong W., Kapturska D., Pecyna MJ., Schulz E., Schloter M., 2014. Influence of Different Forest System Management Practices on Leaf Litter Decomposition Rates, Nutrient Dynamics and the Activity of Ligninolytic Enzymes: A Case Study from Central European Forests. PLoS ONE 9(4): e93700. DOI: 10.1371/journal.pone. 0093700

Sagheb talebi k., Sajedi T., Pourhashemi M., 2013. Forests of Iran. Springer Netherlands, PP.152.

Sariyildiz T., Tüfekçioĝlu, Küçük M. 2005. Comparison of decomposition rates of beech (Fagus orientalis Lipsky) and spruce (Picea orientalis (L.) Link) litter in pure and mixed stands of both species in artvin, Turkey. Turkish Journal of Agriculture and Forestry 29: 429-438.

Shahsavari A., 1997. The Hyrcanian province phytogeographical and paleobotanical studies of the south of Caspian Lake. Research Institute of Forests and Rangelands, Tehran, Tech. pub. No. 125, 48p

Silver WL., Miya RK., 2001. Global patterns in root decomposition: comparisons of climate and litter quality. Oecologia 129:407- 419. DOI: $10.1007 /$ s004420100740

Staaf H., Berg B., 1982. Accumulation and release of plant nutrients in decomposing Scots pine needle litter. Longterm decomposition in a Scots pine forest, II. Canadian Journal of Botany 60:1561-1568. DOI: 10.1139/b82199

Titus BD., Malcolm DC., 1999. The long-term decomposition of Sitka spruce needles in barsh. Forestry 72:207221. DOI: $10.1093 /$ forestry/ 72.3.207

Vesterdal L., 1999. Influence of soil type on mass loss 
and nutrient release from decomposing foliage litter of beech and Norway spruce. Canadian Journal of Forest Research 29: 95-105. DOI: 10.1139/x98-182

Zhou G., Guan L., Wei X., Tang X., Liu S., Liu J., Zhang D., Yan J., 2008. Factors influencing leaf litter decomposition: an intersite decomposition experiment across China. Plant Soil 31:61-72. DOI: 10.1007/s11104-0089658-5

Zohary M., 1973. Geobotanical foundations of the Middle East, 2 vols, G. Fischer, Stuttgart, 739 p.
Zhang D., Hui D., Luo Y., Zhou G., 2008. Rates of litter decomposition in terrestrial ecosystems: global patterns and controlling factors. Plant Ecology 1: 85-93. DOI: 10.1093/jpe/rtn002

Zhang L., Zhang Y., Zou J., Siemann E., 2014. Decomposition of Phragmites australis litter retarded by invasive Solidago canadensis in mixtures: an antagonistic nonadditive effect. Scientific report 4: 5488. DOI: 10.1038/ srep05488 